Retailers' press release activity: market signals for stakeholder engagement?

\author{
Paul Whysall
}

Nottingham Business School

Nottingham Trent University

Autobiographical note:

Paul Whysall is Professor of Retailing at Nottingham Business School, Nottingham Trent University. In recent years he has published several articles on the ethical aspects of retailing and on applications of stakeholder thinking to the field of retailing.

Prof. P.T. Whysall

Nottingham Business School

Nottingham Trent University

Burton Street

Nottingham NG1 4BU

U.K.

Tel: $\quad+44(0) 1158482412$

Fax: $\quad$ +44 (0) 1159486512

e-mail:paul.whysall@ntu.ac.uk 


\title{
Retailers' press release activity: market signals for stakeholder engagement?
}

\begin{abstract}
Through analyses of UK supermarkets' press releases, a medium to date that has received little evaluation in marketing, this study suggests that a model of stakeholder engagement offers an appropriate interpretation of the style and content of releases. Supermarkets seek engagement on diverse issues with different mixes of stakeholder groups. However, treating the releases as market signals, and focusing on their effectiveness, demonstrates the central and crucial role of the press as filters and interpreters, standardising the reporting of releases. Thus the supermarkets' intended messages frequently fail to reach intended audiences, and when they do can be significantly reinterpreted, to the extent that claims of positive achievement are reported critically and negatively. Larger chains are found to produce more releases and gain more newspaper coverage, but generally volume of releases does not improve likelihood of press coverage. Areas for future research are suggested.
\end{abstract}

\section{Keywords:}

Stakeholder engagement Market signalling Press Releases

Retailing

Supermarkets 


\section{Introduction.}

Successful retail management demands balancing multiple demands and returns across key stakeholders, while mismanaging stakeholder relationships may have enduring negative effects (author, date to add). Thus, prima facie, it seems retailers must manage communications to key stakeholders to ensure supportive, productive relations. Here, analyses are presented of press releases from leading British supermarkets to explore the tenor and effectiveness of retailer-stakeholder communications. Press releases are widely used corporate communications, yet receive little evaluative attention in the marketing literature. Supermarkets are selected as a competitive, dynamic sector wherein stakeholder relationship management should be crucial.

This research explores major retailers' communications with key stakeholders through press releases, focusing on release effectiveness. Press release activity has not previously been systematically researched in any sector, so the study has potentially wider significance. Moreover, as a new research area, there is a need to build a conceptual basis which is done by conjoining two emergent frameworks: stakeholder engagement and market signalling. Unlike previous market signalling studies, though, direct communication between sender and receiver is not assumed, with the press emphasised as an intermediate message filter and processor.

After reviewing the limited marketing literature concerning press releases, stakeholder engagement and market signalling are introduced. Following methodological explanation, the content of releases is investigated, showing the appropriateness of a stakeholder engagement approach. Viewing releases as market signals leads to analyses of their take-up in newspapers, which often appears limited. Moreover the previously ignored role of the press emerges as an important moderator.

\section{Press releases in the literature.}

Press releases attract limited attention in marketing. To Kotler et al. (1999, p. 830) press relations involve "placing newsworthy information in the news media to attract attention". Dibb et al. (2001) contend news reports appear more objective than advertising, increase visibility and counter negative imagery. Treatment is also limited in marketing communications texts. Fill (1999) devotes just eight lines to processing releases in over 600 pages. Coulson-Thomas (1987) provides concise advice for effective releases, advising sparing usage. Smith (2000) suggests $96.8 \%$ of 125 million releases annually in Britain get ignored through poor style and targeting, again emphasising cost and credibility advantages even if control of messages is forsaken. Blythe (2000) suggests increasingly sceptical readers skip advertisements but read editorial coverage, so releases should be newsworthy. Belch and Belch (1998) reiterate the merits of interesting, well targeted releases.

McGoldrick (2002) stresses retailing's diverse publics, notwithstanding a consumer focus, with releases an alternative to costly advertising in 'cluttered' media, but requiring newsworthiness and 'professional' targeting, style, and timing. Newman and Cullen (2002) identify releases as proactive publicity, discussing little beyond costs. Sullivan and Adcock (2002) see releases as appropriate to image-led retailers, reiterating credibility and cost advantages. Again, critical consumer attitudes 
alongside advertising 'noise' explain PR's rising importance to retailers seeking to redress adverse publicity, build relationships and enhance image. Thus generally texts portray press release activity as uncomplicated, emphasising placement, newsworthiness, and simplicity. However little emerges concerning releases' content or wider functions.

Searching electronic databases for marketing or retailing articles containing 'news release' or 'press release' produced many 'hits', but most merely quoted releases. Practical 'guides' to specific sectors were found typically portraying releases as mechanistic and formulaic:

"The primary tool used in public relations is the press release. This is usually a one-page, double spaced commentary. It includes names with titles (they add credibility) and several quotations ..." (Letourneau, 1996, p. 120).

For Sheridan (1997), formulaic releases lacking differentiation were frequently ignored. Yet releases also have strategic functions. Simkin and Cheng (1997) found many electronics firms monitored competitors' releases. Positive reactions to announcements may enhance reputation and improve share prices (Gilley et al., 2000). But release effectiveness is questionable. Marken (1993-4, p. 47) argued that, despite widespread use, releases "inform but they don't persuade or sell".

Reportedly, then, releases should be simple, formulaic documents, but paradoxically may serve diverse, strategic functions. Do simplistic views, largely from the communications literature, underplay releases' strategic potential across wider audiences? Clearly there is a need to research the content and functions of press releases, particularly in sectors, like retailing, where stakeholder relations are important.

\section{Towards a conceptual framework: (1) stakeholder engagement.}

Even stakeholder theory's critics such as Sternberg (1997, p. 9) concede "business cannot afford to ignore any stakeholder concern that might affect its ability to generate long-term owner value". The simplest view of stakeholder management sees the business focal to independent, dyadic interactions, trading-off interests (Figure I).

"take in Figure I"

However Andriof et al. (2002, p. 9) reject this 'corporate-centric model':

"From the original 'spoke and wheel' design ... stakeholder thinking has evolved into the study of interactive, mutually engaged and responsive relationships that establish the very context of doing modern business".

They propose a "network-based, relational and process-oriented view of companystakeholder engagement" reflecting mutuality and interdependence. Stakeholder groups are not discrete and isolated; the modern firm must "answer the simultaneous demands of multiple stakeholders" (p. 35), partnering and engaging with clusters of stakeholders.

Although having implications beyond PR, stakeholder engagement would generate appeals to clusters of interest groups, seeking involvement rather than delivering information. Stakeholder engagement, though, seems more about why firms should 
send such messages than how those messages are transmitted or received. Thus further underpinning is needed with a locus in marketing communications.

\section{Towards a conceptual framework: (2) competitive market signalling.}

Competitive market signalling, including preannouncements, provides linkage from press releases to the marketing literature. Heil and Langvardt (1994, p. 83) argue "competitive market signalling constitutes a necessary, natural, and vital facet of competitive behaviour". Press releases, as manifestations of market signalling, contain many examples of what Eliashberg and Robertson (1988) and Heil and Robertson (1991) term preannouncements. However other releases lack preannouncements' characteristics, being retrospective or reactive. Calantone and Schatzel (2000) propose a broader definition of preannouncements including firms' communications concerning future industry states, yet many releases studied here are broader yet in content and motives. Heil and Robertson (1991) researched competitors as targets but Eliashberg and Robertson (1988) anticipated wider audiences for preannouncements. Calantone and Schatzel (2000, p. 27) suggest a "preannouncement can be directed at one or more industry constituents, such as buyers, channel members, employees, investors, industry influencers, and government agencies", and such diverse audiences are revealed here.

However, this study differs from much previous signalling or preannouncement literature in several respects:

- This study explores 'real' data, not experimental situations or theoretical models. Boulding and Kirmani (1993) noted the absence of explicit empirical testing of signalling theory, with their study subject to "the usual caveats of lab experiments" (p. 120). Lilly and Walters (2000) developed experimental settings, noting actual preannouncements may vary in unexamined respects, such as branding. Prabhu and Stewart (2001, p. 70) accepted their gametheoretic experiments "remain somewhat artificial", suggesting different industries may exhibit different forms of signalling. Le Nagard-Assayag and Manceau (2001) calibrated their model to real data, but assumed that all preannouncements were appropriately received and interpreted, and always impacted positively on expectations.

- The sender's perspective is emphasised here. Heil and Walters (1993, p. 54) suggested: "We focus on the perceived or interpreted signal ... It is entirely correct to contend that the intended signal, as opposed to received signal, is an important facet of competitive market signaling and needs to be researched."

- This study does not presume particular strategic intentions. Heil and Walters (1993) argue signalling researchers cannot judge motives, only observe actions. Nevertheless undoubtedly (pre)announcements "may be assumed to reflect the mind-set of the firm's leading strategists" (Calantone and Schatzel, 2000, p. 18). The approach here parallels Calantone and Schatzel's concept of 'competitive equity building' whereby (pre)announcements are seen not just as strategy insights but articulating vision to broad audiences and marketingrelated.

- Prior studies have often been narrowly focused (e.g. new products, competitor reactions), arguably only catching limited parts of firms' market signalling. For Calantone and Schatzel (2000) such narrowness "may restrict understanding of preannouncements to only discrete, single events that are 
highly situation specific" (p. 17). Here, in exploring all of each retailer's press releases, it is assumed, via stakeholder engagement, that multiple recipients may simultaneously receive and interpret diverse signals.

- Most signalling studies envisage direct sender-receiver relationships: "Signalling ... allows efficiency and ease of communications between firms" (Herbig and Milewicz, 1996, p. 36) with "... the number and content of marketing signals ... controlled by the sender" (Herbig \& Milewicz, 1995, p. 37). Here the press are posited as active intermediaries, filtering and reinterpreting signals.

Calantone and Schatzel (2000, p. 17) observe "no broad investigation has examined a firm's propensity to preannounce future actions across a wide range of content despite recent emphasis on communication as an enabler of many stakeholder relationships". Schatzel, Droge and Calantone (2003) argued news wire preannouncements were extensive in content and may reach diverse groups. This study investigates actual signalling across one highly competitive sector. Benefits from adopting a wider stakeholder-framework of receivers reflect both that key constituents - notably consumers - have been under-researched thus far (Lilly and Walters, 2000) and that when different constituencies are addressed, their needs and propensities differ; hence Le Nagard-Assayag and Manceau (2001) advance different managerial implications regarding consumers and channel partners.

\section{Research questions.}

With limited prior understanding of press releases and few empirical researches into market signalling, this study adopts a largely exploratory approach and addresses four broad questions:

- What characterises supermarkets' press releases in terms of style and target audiences?

- How effectively are those characteristics reflected in subsequent press coverage?

- Does size of chain influence release effectiveness?

- What effects do the press have as signal-intermediaries?

Academically, answering these questions will fill an important gap in our understanding of market signalling processes, as well as shedding light on the role and effectiveness of press releases as part of image management.

\section{Methodology.}

Releases were sourced from on-line archives of leading British supermarkets: Asda, Co-operative Group, Iceland, Safeway, Sainsbury, Somerfield, and Tesco. Morrisons, the only other significant chain, offered no comparable archive. Industry data suggests these firms accounted for $81 \%$ of British grocery spending.[1] Supermarkets were examined as representing that part of retailing that most impacts on daily lives, thereby having considerable implicit 'newsworthiness', and also being a dynamic and competitive sector where 'state of the art' practices might be expected. Altogether, 559 releases were identified. Archives may have omissions, but their contents for the period 1 January 2001 to 31 December 2002 on 23 January 2003 was taken as representing retailers' signals to stakeholders. Release take-up was gauged from electronically searching the FT.com 'Top World Sources' database plus popular UK 
newspapers, thus reaching all the leading national, regional and financial newspapers in Britain. Table I lists newspapers in which stories were located. An extensive database of over 550 releases traced to around 800 reports over two years resulted.

This study adopts content analysis initially to gain insights into the nuances and richness of textual data, although recognising a common criticism of this type of analysis that the researcher highlights those aspects which fit a preconceived perception (Easterby-Smith et al., 1999). That criticism can be levelled here - in that appropriate examples were sought, and found. The number of examples that could be presented, and indeed are presented elsewhere (author, date), suggests that aspects of stakeholder engagement genuinely are common across many releases, although like all such evidence it remains for the reader to be convinced - or not. Certainly further studies might add strength to these claims, as is suggested in discussing limitations later. For the subsequent analyses of reported releases, though, such problems are less relevant when all that is being sought is evidence of factual correspondence between release and press reports, with minimal subjective judgement.

Simply because elements of a release appear in a press report cannot confirm that the release triggered the report, so numbers of 'hits' - as releases traceable in newspaper reports - may over-emphasise release effectiveness. It was assumed coverage generated by a release would follow quickly, with searches extending one week after a release's issue. Often, published stories were more critical or less flattering than releases, as will be evidenced, but no qualitative distinction was initially employed.

"take in Table I"

\section{The content and style of press releases.}

Releases, reflecting formulaic tendencies, were readily categorised.[2] Two themes co-existed in a few releases, and these were considered 'half releases'. Categories are listed in Table II. Releases vary in length, and alternative channels exist for communication, so caution is advised in interpreting these percentages. Yet insights result into matters companies seek to communicate to stakeholders, the diversity of themes suggesting concomitant diversity of target. Differences emerged between companies, however, in release content. Asda's emphasis on products and services, promotions and prices may reflect influences of the parent company Wal-Mart; contrastingly the prominence of corporate affairs and senior appointments at Sainsbury's reflects a difficult period of intense competition perhaps.

"take in Table II"

Stakeholder engagement intentions appeared in retailers' signals to farmers. Tesco saw themselves central to a stakeholder network of farmers, suppliers, and customers: "after a great deal of hard work by our staff, suppliers and farmers. ... it's a credit to them, our suppliers and farmers that there has always been enough meat for our customers." (8.3.01)

Tesco's 'language of engagement' purportedly reflected what customers 'told' them: "... customers from all walks of life ... are telling us that they want to buy more organic food" (1.11.01) 
Similarly Sainsbury's "sought the views of farmers on ways in which the company could work more closely with them to understand customers needs" (28.6.02), appointing a manager to improve communications "from farmer to supermarkets to help guarantee that greater efficiencies are operated to the benefit of all involved" (17.9.02).

Tesco, significantly mentioning 'market signals', sought improved supply chain communication through a stakeholder network comprising:

"... all the businesses involved in the Dairy value chain - from farmers to distributors, processors and Tesco. ... In this way, we can help transmit market signals along the supply chain and in turn understand better the issues that producers face." (14.3.02)

Somerfield similarly depicted an active network, wanting "to talk directly to farmers about ... how they can work together with supermarkets and suppliers" (8.1.01). Later, Somerfield wanted "customers ... to link through us to their neighbourhood." (9.11.02), language redolent of a network of interests with the retailer focal.

Stakeholder engagement also accompanied charitable campaigns:

"All ASDA stores aim to play an active part in local life and ... to enable stores to achieve 'store of the community' status ... includes demonstrating good relationships with local MPs, Councillors, emergency services, schools and charities" (4.5.02).

Store development releases were replete with imagery of networks and shared interests. Tesco even offered to "advise the Government on what good community involvement looked like" (19.3.02). In a scheme promising jobs, environmental improvement and business regeneration, Tesco were "inspired by the Council's vision", wanting "to work with the Council and local people" (4.6.01). Other examples of stakeholder engagement appeared in releases about health-related initiatives and Fair Traded goods.

All supermarkets sought to demonstrate involvement in networks of interests for the greater good, even if customers' interests were emphasised. The language of diverse linkages and dialogues was consistent with expectations under stakeholder engagement.

\section{Press release effectiveness - comparisons across retailers.}

Interesting relationships emerge between release activity, press coverage, and firm size (measured by turnover):

- Releases issued per chain correlate significantly with turnover [3] $(r=0.811$; significant at 0.05 level)

- Releases reported correlate highly significantly with turnover $(r=0.934$; significant at 0.01 level)

- Total reports per retailer correlate highly significantly with turnover $(\mathrm{r}=$ 0.958 ; significant at 0.01 level)

Thus while larger chains issue more releases, more significantly, they are reported more frequently. Yet causalities remain unknown. Does releases activity reflect company resources or $\mathrm{PR} /$ marketing strategies? Perhaps a belief that editorial interests favour larger chains discourages smaller chains' release activity. Notably, size is a stronger correlate of press reporting than of release activity. 
Smith (2000) suggested $96 \%$ of press releases are discarded. A very different measure here suggests $38 \%$ of all releases issued were subsequently reported at least once. Two measures of relative release impact are calculated: percentage of releases reported at least once, and numbers of reports per reported release (Table III). Analyses found:

- No significant relationship between proportions of releases gaining press coverage and turnover $(r=0.722 ; \mathrm{p}=0.067)$.

- No relationship whatsoever between turnover and reports per story $(r=-0.017$; $\mathrm{p}=.971)$.

Turnover is no indicator of release success, then, bearing no relationship whatsoever to extent of coverage. Editorial judgements of newsworthiness appear more important than patterns of release activity: while larger chains produce more releases, that does not increase coverage per story.

"take in Table III"

\section{Press releases effectiveness - comparisons across story category.}

Take-up was also analysed across categories of story (Table II). Categories differ greatly in volume, and only those with over 10 releases are discussed. Take-up varied markedly. Several categories showed over half of releases being reported, against an average of 38\%: corporate and performance issues (73\%), prices $(66 \%)$, human resources $(61 \%)$, senior appointments $(58 \%)$ and job creation $(56 \%)$. Contrastingly, categories with under a quarter of releases generating coverage included awards (3\%), corporate social responsibility (14\%), supply chain/farming issues $(22 \%)$ and property deals (24\%). Some categories may find coverage in specialist publications, however. Evidence supporting stakeholder engagement was prominent within CSR (notably charitable) activity and relations with farmers, but actual reporting was limited. Retailers' attempts to portray themselves as 'farming friendly' spread across categories, but taken together only $26 \%$ of releases generated reports.

Using a second impact measure, on average each reported story appeared in 3.77 newspapers, yet only corporate and performance issues exceed this (7.58), followed by prices (3.66). Least reported are promotional activity (1.16), foot and mouth disease (1.55), awards (2.0), job creation (2.26), supply chain and farming matters (2.26), and senior management (2.55).

Synthesising impact measures suggests:

- Newsworthy categories are reported often and widely, notably corporate performance, plus, to a lesser degree, prices. Editorial interest traces the performance of these prominent businesses, often as 'winners' or 'losers'.

- Awards and supply chain issues make little impact on either measure. They may find specialist coverage, but press editors do not see them as newsworthy.

- Some categories find isolated but not widespread reporting: job creation may achieve regional coverage in relevant localities, while senior management matters typically find coverage in the business/financial press. 
- Fourthly are categories that go largely unreported, although occasionally gaining wider coverage. Within the CSR category, charitable activities were not reported widely, yet innovative environmental initiatives, such as biodegradable packaging from potatoes and degradable carrier bags proved newsworthy.

Press interest, notably in performance and prices, apparently determines coverage, notwithstanding supermarkets' efforts to promote wider issues. Spearman's rank correlation $(r=-0.030)$ confirms no significant relationship exists between releases per category and tendency to be reported: again, volume of releases does not generate coverage.

Contrasting relationships emerge between profiles of retailers' release categories and subsequent reporting (Table IV). Retailers' releases demonstrate diversity, only 5 of 21 relationships proving highly significant. Yet considerable similarity exists in subsequent reporting, with 14 of 21 relationships highly significant. All 6 nonsignificant relationships involved American-owned Asda, whose performance reporting, the most reported category, consequentially differs from the others. Hence even these 6 non-significant results may represent 'special cases'.

"take in table IV"

Retailers, then, send diverse signals to stakeholders, but the press as 'gatekeepers' of newsworthiness report preferred themes regardless. Thus editorial policies seemingly thwart supermarkets' search for diversified stakeholder engagement through press releases.

\section{And the message may change!}

A retailer might reasonably, though, anticipate widespread coverage of positive performance. On 10 April 2001, Tesco released details of record-breaking profits, typically citing stakeholder benefits:

- Shareholders benefited through dividends.

- Tesco was "totally focused with getting it right for customers ... while cutting prices, we constantly respond to other customer needs".

- Tesco welcomed the Competition Commission's report, intending to cooperate with it.

- "(W)orking closely with the farmers' unions ... Tesco has stood by British farmers ... and this has significantly benefited farm incomes ... Farmers know they can count on the support of Tesco customers and staff."

- New stores "tailored to the needs of different customers" enabled "partnerships throughout the UK ... providing jobs, training, subsidised transport and childcare".

The message was of engagement and shared benefits across stakeholders.

The Scotsman, under an apparently supportive headline celebrating jobs for Scotland, reported withering criticisms:

"Farming and consumer groups reacted to Tesco's record profits with a stinging attack on the supermarket giant and called on shoppers to think twice before shopping in its stores. 
The National Consumer Protection Council called on shoppers to go elsewhere if they could find cheaper goods, while rural representatives said farmers would find the profit levels 'hard' to comprehend." (11.04.01)

The Irish Independent reiterated criticisms, while The Times reported Tesco's denials profits were at consumers' expense. The Guardian reported farmers' accusations that supermarkets were a "new food baronial class", and calls for a regulator not "in the pockets of the supermarkets". The Independent's headline was "Farmers savage Tesco over 'obscene' $£ 1$ billion profits", while the Financial Times proclaimed: "Tesco chief defends $£ 1$ bn profits" quoting Tesco's CEO denying supermarkets were to blame for foot-and-mouth!

Thus Tesco's press release and what the press reported differed diametrically. We may usefully recall the warning that while press coverage brings advantages, it also means control of the message is lost (Smith, 2000).

\section{Concluding remarks, limitations, and implications.}

This paper makes a number of contributions: it offers a rare evaluative insight into press releases as market communications, and contributes to the literature of market signalling by developing a broad, sender-based, empirical study. Importantly, it introduces a notion of signal intermediaries, the press in this case.

In relation to the four research questions posed, it can be concluded:

- Supermarkets' press releases are characterised by a style in line with expectations from stakeholder engagement, of attempted dialogue, bridgebuilding and partnering with stakeholders. Correlation analysis suggests releases show considerable diversity across retailers, apparently targeting different sets of stakeholders.

- Despite diversity in release activity, press coverage shows consistency across retailers, with all exceptions attributable in part at least to Asda's American ownership.

- Larger chains issue more releases, and get more coverage, yet higher turnover does not increase proportions of releases reported, or the extent of coverage.

- The press plays a crucial role imposing its own agenda on news coverage, largely in disregard of retailers' strategies to differentiate through signalling. The press has the ability totally to reinterpret news coverage.

Even if retailers believe themselves focal to stakeholder networks, as releases imply, they neither control the range of issues reported nor the content of reporting. Rowley (1997) suggested stakeholder networks are better understood by thinking of all connections between groups, and the ability to exercise power. Retailers' inability to control news agendas may reflect stronger 'stakeholder $\rightarrow$ press' linkages by-passing retailers in comparison with supermarkets' intended 'retailer $\rightarrow$ media $\rightarrow$ stakeholder' channel. Other stakeholders (e.g. farming, consumer groups) clearly have effective linkages to the press (as the Tesco example demonstrates), and journalists probably believe they better understand what their readerships wish to hear. There is evidence here that implies retailers' search for stakeholder engagement through the press is currently not effective, suggesting they should either review the appropriateness of the medium for that purpose or take fuller note of the press's roles, perceptions and news agendas. To attempt to engage with stakeholders through the intermediary of the 
press needs either acceptance of the loss of control this implies or must seek to work within the constraints of press interest.

An interesting contrast emerges, then. Despite diverse attempts by retailers to engage with different stakeholder mixes, relatively consistent patterns of reporting result, through the press, as an intervening filter, imposing their own, sometimes retailerunfriendly, interpretation on signals. The emergence of the press as an influential moderator of market signals is a significant contribution. Perhaps we should treat the press as a stakeholder, one firms need better to engage with. More generally, this reinforces the obvious caveat to non-empirical signalling studies that signals sent may not be received as intended, if at all.

Limitations to this study include the nature of the data, the limited time frame used, and possible omissions from data archives. Nonetheless, useful and original insights have been gained from an extensive data set, and there remains considerable scope for further study. One might usefully look into release take-up across different media, both within the sources explored here (e.g. the financial and regional presses) and more widely (e.g. non-print media, publications for specific stakeholders). A broader framework which seeks to integrate understanding of one set of signals (i.e. press releases) with others (e.g. annual reports, analyst briefings, advertising, in-store communications) would more fully test the relevance and robustness of the market signalling paradigm. Finally, it would be useful to ascertain if findings from this study of British supermarkets, and notably the role of the press that emerges, is replicated in other sectors and other countries.

Managerial implications of such an exploratory study can only be tentatively offered, and then in the light of the limitations and further research needs set out above. The lack of clear relationships between turnover and release success is one area that merits reflection. Larger chains did generate more releases, perhaps simply reflecting their greater scales of activity, and did receive more press coverage, as might be expected. However the proportion of releases reported did not correlate significantly with turnover, while extent of coverage appeared totally independent of turnover. This raises a question: are the larger chains 'trying too hard'? Would they get similar levels of coverage if they concentrated releases on those areas shown to attract editorial attention, and save resources in so doing? Secondly, but linked, the search for differentiation through press releases appears not to have been very successful for these retailers. Is seeking differentiation an activity for which the press release is an inappropriate vehicle, given editorial priorities? Might these efforts be directed into communication channels less prone to intermediate filtering? Or should the press be seen less as an external 'market' for releases, and more as another stakeholder group to understand and engage with?

[1] TNS Superpanel customer spend (GB) for 12 weeks to 13.10 .02

[2] To check consistency a 10\% sample of stories was independently classified by a non-specialist, with few differences emerging (3 in 55), save some where stories were allocated to two categories.

[3] TNS Superpanel customer spend (GB) for 12 weeks to 13.10 .02 


\section{References.}

Andriof, J., Waddock, S., Husted, B., and Rahman, S.S. (2002), Unfolding Stakeholder Thinking, Greenleaf Publishing, Sheffield.

Belch, G.E. and Belch, M.A. (1998), Advertising and Promotion. An integrated marketing communications perspective, Irwin McGraw-Hill, Boston.

Blythe, J. (2000), Essentials of Marketing Communications, FT Prentice Hall, Harlow, Second Edition.

Boulding, W. and Kirmani, A. (1993), "A consumer-side experimental examination of signalling theory: do consumers perceive warranties as signals of quality?", Journal of Consumer Research, Vol 20, June, pp. 111-123.

Calantone, R.J. and Schatzel, K.E. (2000), "Strategic foretelling: communicationbased antecedents of a firm's propensity to preannounce", Journal of Marketing, Vol 64, Jan, pp. 17-30.

Coulson-Thomas, C.J. (1987), Marketing Communications, Heineman, London.

Dibb, S., Simpkin, L., Pride, W.M. and Ferrell, O.C. (2001), Marketing. Concepts and Strategies, Fourth European Edition, Houghton Mifflin, Boston.

Easterby-Smith, M., Thorpe, R., and Lowe, A. (1999), Management research. An Introduction, Sage, London.

Eliashberg, J. and Robertson, T.S. (1988), "New product preannouncing behaviour: a market signaling study", Journal of Marketing Research, Vol 25, Aug, pp. 282-292.

Fill, C. (1999), Marketing Communications. Contexts, contents and strategies, Second Edition, Prentice Hall Europe, London.

Gilley, K.M., Worrell, D.L., Davidson, W.N. and El-Jelly, A. (2000), “Corporate environmental initiatives and anticipated firm performance: the differential effects of process-driven versus product driven greening initiatives", Journal of Management, Vol 26 No 6, pp. 1199-1216.

Heil, O.P. and Langvardt, A.W. (1994), "The interface between competitive market signaling and antitrust law”, Journal of Marketing, Vol 58, July, pp. 81-96.

Heil, O.P and Robertson, T.S. (1991), "Toward a theory of competitive market signaling: a research agenda", Strategic Management Journal, Vol 12, pp. 403-418.

Heil, O.P and Walters, R.G. (1993), "Explaining competitive reactions to new products: an empirical signaling study", Journal of Product Innovation Management, Vol 10 No 1, pp. 53-65. 
Herbig, P. and Milewicz, J. (1995), "The impact of market signals on strategic decision-making ability and profitability", Market Intelligence and Planning, Vol 13 No 7, pp. 37-46

Herbig, P. and Milewicz, J. (1996), "Market signalling: a review”, Management Decision, Vol 34 No 1, pp. 35-45.

Kotler, P., Armstrong, G., Saunders, J. and Wong, V. (1999), Principles of Marketing, Second European Edition, Prentice Hall Europe, London.

Le Nagard-Assayag and Manceau, D. (2001), "Modelling the impact of product preannouncements in the context of indirect network externalities", International Journal of Research in Marketing, Vol 18 No 3, pp. 203-219.

Letourneau, T. (1996), “The spokes of the marketing wheel”, Bank Marketing, July, pp. 117-122.

Lilly, B. and Walters, R.G. (2000), “An exploratory examination of retaliatory preannouncing”, Journal of Marketing Theory and Practice, Vol 8 No 3, 1-9.

McGoldrick, P.J. (2002), Retail Marketing, Second Edition, McGraw-Hill, Maidenhead.

Marken, G.A. (1993-4), "Effective public relations ... More than a few news releases", Public Relations Quarterly, Winter, pp. 47-48.

Newman, A.J. and Cullen, P. (2002), Retailing: Environment and Operations, Thomson Learning, London.

Prabhu, J. and Stewart, D.W. (2001), "Signaling strategies in competitive interaction: building reputations and hiding the truth", Journal of Marketing Research, Vol 38 No $1,62-72$.

Rowley, T.J. (1997), "Moving beyond dyadic ties: a network theory of stakeholder influences", Academy of Management Review, Vol 22 No 4, pp. 887-910.

Schatzel, K., Droge, C. and Calantone, R. (2003), "Strategic channel activity preannouncements. An exploratory investigation of antecedent effects", Journal of Business Research, Vol 56, pp. 923-933.

Sheridan, K. (1997), “Depressing releases”, Bank Marketing, Vol 29 No 4, pp. 51-60.

Simkin, L. and Cheng, A. (1997), “Understanding competitors' strategies: the practitioner-academic gap", Marketing Intelligence and Planning, Vol 15 Nos 2-3, pp. 124-134.

Smith, P.A. (2000), Marketing Communications. An integrated approach, Kogan Page, London. 
Sternberg, E. (1997), 'The defects of stakeholder theory', Corporate Governance, Vol 5 No 1, pp. 3-10.

Sullivan, M. and Adcock, D. (2002), Retail Marketing, Thomson Learning, London. 
Table I: Newspapers successfully searched for Press Coverage.

\begin{tabular}{|l|l|}
\hline Quality Broadsheets & Times \\
& Guardian \\
& Independent \\
& Daily Telegraph \\
\hline Mid-market/Tabloid Newspapers & Express \\
& Daily Mail \\
& Mirror \\
& Daily Record \\
\hline Financial and Specialist Newspapers & Financial Times \\
& Investors Chronicle \\
& Financial Mail (Canada) \\
& Wall Street Journal (US) \\
& Sunday Business \\
\hline UK and Irish Regional Newspapers & Scotsman \\
& Belfast Telegraph \\
& Irish Times \\
& Irish Independent \\
& Birmingham Post \\
& (Glasgow) Herald \\
& Evening Standard \\
\hline Sunday Newspapers & Express on Sunday \\
& Independent on Sunday \\
& Observer \\
& Mail on Sunday \\
\hline
\end{tabular}


Table II: Categories of Press Releases.

\begin{tabular}{|l|r|}
\hline Category & \% releases \\
\hline Products and services & 18.9 \\
\hline Corporate Social Responsibility (CSR) and environmental matters & 15.8 \\
\hline Corporate affairs, performance data, takeovers etc. & 10.1 \\
\hline Prices & 8.2 \\
\hline Promotional and seasonal activity & 7.8 \\
\hline Supply chain issues (including relations with farmers) & 7.3 \\
\hline Senior management appointments and activities & 6.1 \\
\hline Health and dietary matters (including organic \& non-GM produce) & 6.0 \\
\hline Job creation & 3.7 \\
\hline Property, new stores, urban regeneration & 3.6 \\
\hline Stories following an outbreak of foot and mouth disease & 3.0 \\
\hline Awards gained and given & 2.8 \\
\hline Human resource issues (e.g. training, share schemes, pensions) & 2.1 \\
\hline Government (including EU) matters & 1.6 \\
\hline International matters (Tesco only) & 0.9 \\
\hline Product recalls & 0.7 \\
\hline Miscellaneous matters & 1.3 \\
\hline & 100.0 \\
\hline
\end{tabular}


Table III: Impacts of Retailers’ Press Releases.

\begin{tabular}{|c|c|c|c|}
\hline & $\begin{array}{l}\text { Percent Releases } \\
\text { reported at least } \\
\text { once. }\end{array}$ & $\begin{array}{l}\text { Average number of } \\
\text { 'hits' per story } \\
\text { reported }\end{array}$ & $\begin{array}{l}\text { Total number } \\
\text { releases }\end{array}$ \\
\hline Asda & 47.4 & 2.6 & 116 \\
\hline Co-op & 41.7 & 3.7 & 36 \\
\hline Iceland & 14.1 & 4.7 & 64 \\
\hline Safeway & 26.3 & 3.3 & 57 \\
\hline Sainsbury & 56.4 & 4.5 & 78 \\
\hline Somerfield & 17.5 & 3.8 & 80 \\
\hline Tesco & 46.1 & 4.3 & 128 \\
\hline Total: & 37.7 & 3.8 & 559 \\
\hline
\end{tabular}


Table IV: Significance of correlations between categories of news release stories and press reports subsequently arising.

\begin{tabular}{|l|l|l|l|}
\hline & $\begin{array}{l}\text { Number } \\
\text { significant at } \\
\mathrm{p}=0.01\end{array}$ & $\begin{array}{l}\text { Number } \\
\text { significant at } \\
\mathrm{p}=0.05\end{array}$ & $\begin{array}{l}\text { Non- } \\
\text { significant }\end{array}$ \\
\hline $\begin{array}{l}\text { Of 21 correlations } \\
\text { between supermarkets' } \\
\text { releases: }\end{array}$ & 5 & 5 & 11 \\
\hline $\begin{array}{l}\text { Of 21 correlations } \\
\text { between reports of } \\
\text { supermarkets' releases }\end{array}$ & 14 & 1 & 6 \\
\hline
\end{tabular}


Figure 1: A ‘corporate-centric’ view of stakeholder management in retailing.

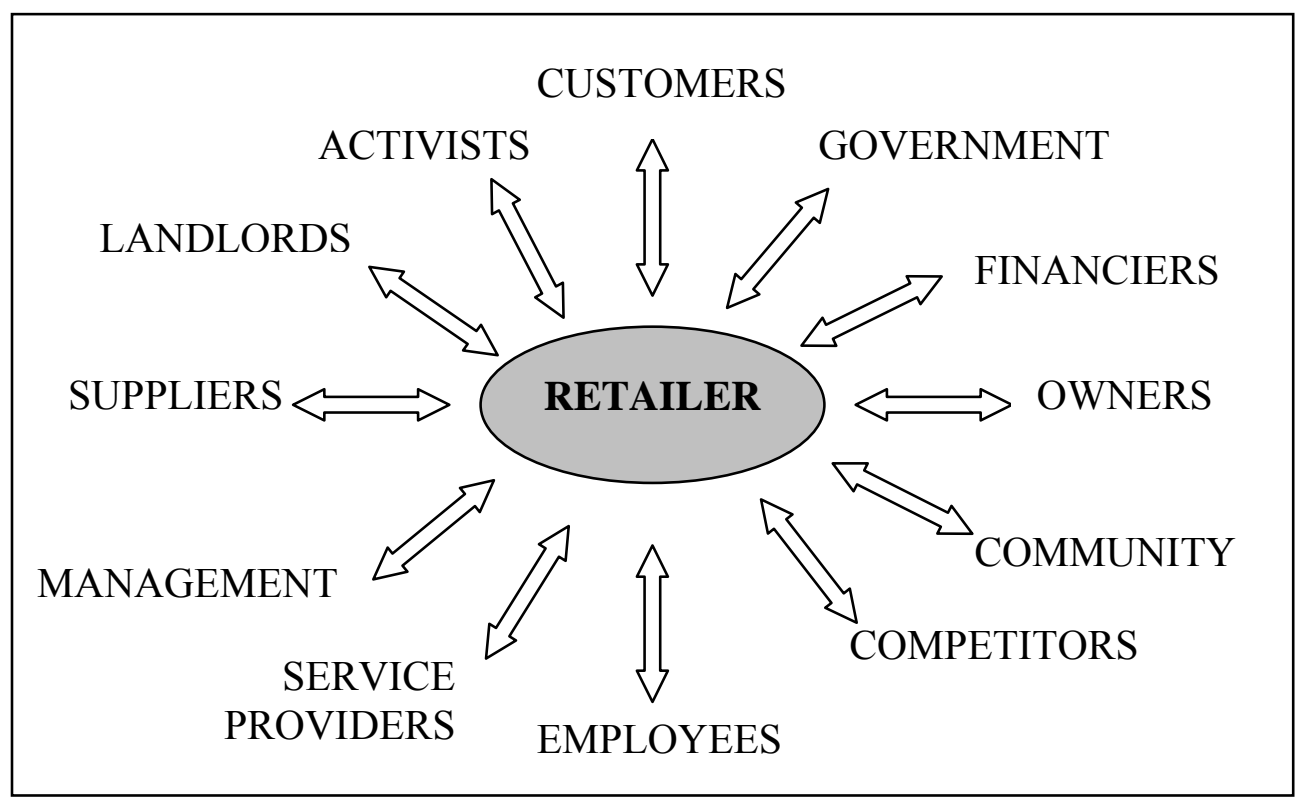


